Vol. 4, No. 1, January 2016

Jurnal llmial

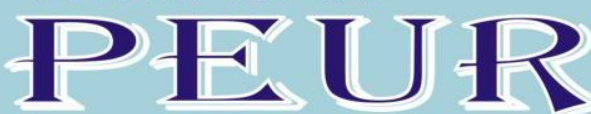

Media Kajian Ilmiah Sosial, Politik, Hukum, Agama dan Budaya
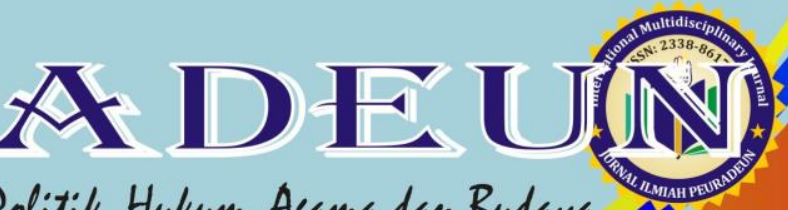


\title{
ART AS A CULTURAL INSTRUMENT: The Role of Acehnese Art in Resolving Horizontal Conflict
}

\author{
Saifuddin Dhuhri \\ Faculty Dakwah and Islamic Communication, \\ State College for Islamic Studies, Malikussaleh, Aceh, Indonesia \\ E-mail: saifuddindhuhri@gmail.com
}

Received: Jul 11, 2015

Accepted: Nov 23, 2015

Published: Jan 21, 2015

Article Url: https://journal.scadindependent.org/index.php/jipeuradeun/article/view/88

\begin{abstract}
This article begins with explaining the present problems of Acehnese cultural identity, then articulating how the art is usefully employed to solve those difficulties. Relying on post-colonial theories, I formulate the framework that Acehnese art has significant position to handling current cultural problem of Acehnese society. This work offers a cultural resolution of Acehnese present conflict between traditionalist and modernist Muslims, which are represented by Dayah and Muhammadiyah community in Aceh. It is commonly known that Islam is the pride of the Acehnese. To date, there is, however, no certainty about the nature of Islam in Aceh, as heated debate still exists between traditionalist and modernist Muslims upon the nature of Sharia application in the place. This dispute has generated different extreme perspectives upon seeing themselves in the way to treat their cultural identity. Here we establishes that Acehnese art plays great role in bringing togetherness to different groups of Acehnese society, which results in resolving horizontal conflict of Acehnese society. It shows that Acehnese art accommodates to all of different ness of Acehnese communities and, therefore, raises Acehnese collective consciousness.
\end{abstract}

Keywords: Acehnese art, Horizontal Conflict, Social Cohesion 


\section{A. Introduction}

Current dispute over the standard Islam of Acehnese communities has mobilized mass of traditionalists ${ }^{1}$, known as Dayah community; go for "ASWAJA Parade" in Banda. Believed themselves as the single standard Islam, traditionalists have vividly demonstrated their grudge against modernist Muslims, which is commonly indicated as Wahabism, in the first and second parades ${ }^{2}$. Many local observers view the parades along with other serial traditionalist events have political tendency and goals. Aryos Nivadas and Saiful Mahdi, for instance, argue the parades are merely plotted against Zaini, the current governor of Aceh. ${ }^{3}$

As shown by many historians, the oldest and the most heated debate under the banner of Ahl al-Sunnah wa al-Jamaah (ASWAJA) between traditionalists and modernists Islam in Aceh, might be in Southeast Asia, was, perhaps, between Nurruddin Ar-Raniry and Syeikh Hamzah Al-Fansury in early 17 century. Although both sides are strongly grounded their arguments in the holy texts of Al-Quran and the prophet Muhammad traditions, they failed to establish the independency of academic tradition in the region because the debate was heavily involved political interventions (Ar-Raniry: 2011; Daudy: 1978). Regardless that failure, the debate between both sides still continues until current time.

This paper is elaborating the role of the Acehnese art in conjoining different groups of Acehnese people and raising the Acehnese collectiveness and social consciousness. The paper commences with elaborating postcolonial view on culture and hegemony. The article will, then, discuss the concept of cultural identity and how is the term related to the state of the Acehnese cultural awareness. Eventually, this work will elucidate the way of the Acehnese art accommodates with various elements of Acehnese ethnicity and culture.

\footnotetext{
${ }^{1}$ The term traditionalist Muslim used in the article refers to Dayah community in Aceh, which has similar meaning to Pesantren in Java and Indonesia in general. Martin van Bruinessen also refers to similar institution in his elaboration of Indonesian tradisionalist. For detail, see Martin Bruinessen (2008). Traditionalist and Islamist Pesantrens in Contemporary Indonesia, (in Farish A. Noor, Y. S)

${ }^{2}$ To date, two ASWAJA Parades have been organised. The first and second parades were successfully accomplished traditionalist goals regarding ibadah performances in grand Mosque of Baiturrahman.

3 Mahdi expressed his view on Facebook threads several times regarding this issue and Nevada was interviewed by local media, he argued the parades are fully political action for bargaining power for the net general election.
} 


\section{B. Acehnese Cultural Identity Construction}

Aceh is one of Indonesian provinces where is situated in the tip of Sumatra island. There are approximately 4 million people living in the tensest endeavour of self-determination society in Indonesia. Aceh has 23 regencies namely Meulaboh, Blangpidie, Jantho, Calang, Tapaktuan, Aceh Tamiang, Takengon, Kutacane, East Aceh, North Aceh, Lhokseumawe, Bener Meriah, Gayo Lues, Siglie, Meureudu, Sinabang, Bireun, Nagan Raya, Banda Aceh, Lhokseumawe, Rekap, Sabang and Subussalam (Government: 2009).

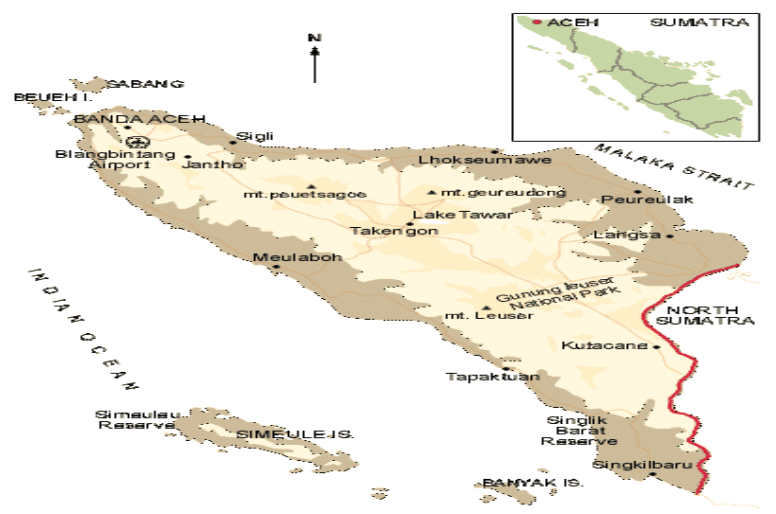

Figure 1: the map of Aceh

Acehnese society is comprised of multiple ethnics and cultures. The majority of Acehnese are either Malayo-Polynesian origin, Arabic and Indian background, or Chinese ancestry. There are eight major cultures: Alas, Aneuk Jamee, Gayo, Kluet, Pulau (Island groups), Singkel, Tamiang, and 'ethnic Acehnese'. The latter comprise around 90 per cent of the total population and are defined by their Islamic background and distinct Acehnese dialects. There are also clusters of Batak, Chinese, Javanese and Minangkabau in the region (Smith: 1997).

Islam is a religion of nearly all of the Acehnese. It influences abundantly Acehnese culture which overlaps all of the Acehnese life matters. This powerful Islamic penetration to Acehnese way of life due the prolonged historical convert of Islam which is known as the first place where Islam was introduced in the entire Southeast Asia (MUI Aceh: 1980; Andaya: 2001; Reid: 2006; M. Said: 1981 and Smith: 1997). 
With various new waves of $D a^{\prime} i$ groups, Islam was started to be converted by Acehnese in the early $8 \mathrm{CE}$ which was covered sparsely some small community of the Acehnese Hindu-Buddhism society. Next two centuries, the number of Muslims had become majority of some regions, such as Peurelak and Samudra Pasai and they established Islamic kingdoms wherein the Islamic teaching center. It is clear from the literature that the Islamic religion is accepted by local people peacefully and friendly (Harun: 1995; Ibrahim: 1991; Ismail: 1993; Latif: 1992; Said: 1981; Zainuddin: 1961).

Based on this prolonged Acehnese historical development, Acehnese cultural identity has been accumulated and sedimented into several practices, which are celebrated by Acehnese people through their routine life. They can be summed up into some sameness traits among Acehnese society namely: Acehnese and sub-Acehnese languages, strong believe in Islamic religion, Seuneujoh (death ritual), Maulid (the ceremony of Prophet Muhammad's birthday), Seudati dance, Saman dance, and the ways to welcoming guests (Aceh Institute: 2008).

There is a dialectic development of Acehnese cultural identity in its history which in some phases, traditions dominated over other traits, and at other time, Islamic values overshadow all the mentioned aspects. In short, the identity of the Acehnese has developed differently from time to time in their history (Bowen: 2007). Among many various identities, Islam traditions and custom (Hurgronje: 1985, 1996), and nationalism (Aspinal: 2009; Lombard: 2006; Hasan Tiro: 1979 and 1984), had become the most dominant in several stages of the Acehnese identity history.

Most Acehnese historians believe that the time when King Iskandar Muda reigned over the Acehnese kingdom in $18 \mathrm{CE}$ was the greatest time. In this time, the idea of Acehnese identity had started to mature and had been accepted by many different groups in the region. Based on Gramsci's theory, it is considered that the time is the Acehnese historical bloc by which this pinnacle era will trigger the Acehnese consciousness of their existence in the present time. The peak of the Acehese kingdom in history has left a good past memory in every Acehnese people. That historical memories of the Acehnese greatness civilization have continuingly triggered the Acehnese people to preserve their heritages which are considered as the worth pride of their cultures (Aceh Institute: 2008; Kartomi: 2004; Reid: 2006). 
In the present time, this pride has created local resistance against central government of Indonesia and brought a great consciousness with their existences among Indonesian majority ethics and global cultures as well (Aspinall: 2009; Aspinal \& Fealy: 2003; Miller: 2009; Reid: 2006; Hasan Tiro: 1979 and 1984). Since the time of Indonesian independence, for instance, the Acehnese has encountered political and cultural tensions between local and central Indonesian government. This cultural instilment, in term of Gramsci; cultural hegemony will deprive the Acehnese cultural consciousness and in the result, the Acehnese people will undergo the state of false cultural consciousness (Gramsci, 1981-1937; Gramsci, Forgascs \& Nowell Smith: 1985); Gramsci, Piccone \& Cavalcanti: 1975). This condition undermines the embodiment of local political and economic interests. In the short stage, this cultural hegemony will lead to remove the Acehnese identity and culture from Indonesian mainstream society, whereas in the long phase, this hegemony will give the justification for dominant group to exploit the Acehnese resources.

\section{Horizontal Conflicts}

Nielsen (2002) has delimited the scope of internal/horizontal conflict to only the conflict between Acehnese aristocrats who welcomed the presence of the Dutch and elite PUSA. I use the term more broadly here to encompass all related internal cultural and coercive conflict. Motivated by the spirit to fight against the Dutch and to implement Shari'a in Aceh in 1953, the Acehnese led by elite Ulama from the PUSA organisation fought against the local aristocrats who supported the return of Dutch rule (Prang: 2008). This conflict reached its peak when the Ulama began to war against the UleiBalang in 1946. The war broke out in the town of Lamlo in Pidie (Khuluq: 2002; Prang: 2008; Reid: 1979; Siegel: 1969).

Following that coercive conflict, the horizontal conflict had extended to the issue of competing interpretations and teachings of Islamic culture. At this time, Dayah and traditional Ulama were challenged by the reformist Islam or the All-united Aceh Ulama (PUSA), who were enlightened by modern Islamic thought, such as Muhammad Abduh, Afghani and other figures of PAN-Islam (Formichi, 2010: 344; 
Keddie: 1969; Latif: 1992; and Siegel: 1969). The PUSA believes that traditional teachings of Islam, advocated by the Dayah Ulama are heresy, such as Peusijuek, ${ }^{4}$ Seuneujoh, Meuled, and so on. During Daud Beureueh's and Ali Hasjmy's eras as Aceh governors, the Islam reformists were becoming stronger because of their support. The governors along with MPU issued a regulation that prohibited the practice of traditional ritual (El-Ibrahimy: 1982 and Siegel: 1969).

Even though the reformists were in power at that time, there were many traditional Muslims, like the Dayah community, ${ }^{5}$ still strongly opposed to reformist ideology. The Dayah communities were against the regulation preventing the practice of traditional Islamic rituals. They considered the reformists did not have the right to prohibit the rituals since those practices are part of Islamic teaching. Therefore, the reformists were misguided, and infidels. As noted by Ricci (2011: 533), many Arabic texts had been interpreted in different ways in Southeast Asia. As such, such differences of interpretation had motivated many cultural conflicts. Although the reformists had political power, they had difficulty facing the traditionalist opposition for two reasons. Firstly, the Dayah community was supported by the majority of Acehnese. Secondly, those rituals suspected of heresy, were the markers of Acehnese cultural identity (Dhuhri: 2008a and 2009b).

${ }^{4}$ Peusijuek is a traditional ritual performed for well-being. This ritual needs some ingredients, such as fresh leaves, rice, and paddy and water. Also, the performer cast spells for blessing persons in the ritual.

${ }^{5}$ Dayah had been introduced since the beginning of Acehnese cultural emergence in Southeast Asia. When travellers or da'i from Arab, Gujarat, and India came to Aceh, they established an Islamic education institution, later called Dayah, in order to Islamise the region and to maintain the implementation of Islamic teachings. Although there is little hard evidence, the Acehnese believe that Islamic traditional education in the Southeast Asia region started in Aceh. It began in the 10th century and reached its peak of development in the 16th century. This was believed to be the golden age of Islamic education. For example, it is believed that Dayah Baiturrahman was a university with 17 faculties. Dayah Cot Kala was the first centre of Islamic higher education in Southeast Asia. It made a massive contribution to the spread of Islam throughout the archipelago. It produced many scholars, which became da' $i$ in the regions. Although education was conducted merely by sitting in a semi-circle around the teacher, this Dayah laid an important foundation in Acehnese history because the alumni of the Dayah would go on to establish their own Dayah in another area, where Islam was not yet the dominant religion. This process is central to the Islamisation of the Acehnese community (for more detailed information, see chapter four (4.4.2), Schools and ideology). 
To sum up, Identity, as Joseph (2003 and 2006) aptly posits, is simultaneously subjective (experienced by the individual) and constituted in and through culture (the collective). From this perspective, an individual's identity is shaped by multiple discourses but he/her self is part of this historicized and fluid process whereby her/his identity is created. Subjectivity is produced not by external ideas, values or material causes, but by one's personal subjective engagement in the practices, discourses and institutions that lend significance (value, meaning and affect) to the events of the World (Joseph: 2003; Joseph \& Ozga: 2006).

At any given time, a collectivity will have specific dominant processes of social interaction, institutions and traditions. In the context of Acehnese people, traditions, Islamic beliefs and traditional arts illustrate the categories of the Acehnese cultural markers. An individual having lived and immersed oneself within a particular collectivity will have assumed some of the signifying practices of that collective. Commonalities of experience within the ethnic collectivities result in a certain degree of sameness in the selfidentifications of members of an ethnic or cultural group. Hence, Acehenese people are constantly in negotiation with the social and cultural discourses in which they are immersed. As a result, their own subjective selves are simultaneously shaped by, and help shape, the collective discourses.

\section{Acehnese Art as the Anchor of the Discrepancies}

Cultural theorists have sought the consensus that art is part of cultural heritage (Al-Faruqi: 1973); Crickmay: 2003; Dewey: 1959; Eisener: 2007; Hatcher: 1999; Kartomi, 2004; Mwenesi: 1998; Smith: 1997). This article posits that art is greatly useful instrument for developing social cohesion. In the Acehnese context, Acehnese arts have underpinned the Acehnese cultural identity and they are considered as the core of the Acehnese cultural identity in which aesthetically always accommodate all of the Acehnese different identities. It can be explored by analyzing the elements of Acehnese art. In doing so, we can hypothetically classify the Acehnese art into the traditions group, Islamic teaching genre, earning livelihood group, ethnic groups and so forth. This can be described as the chart indicates below. 


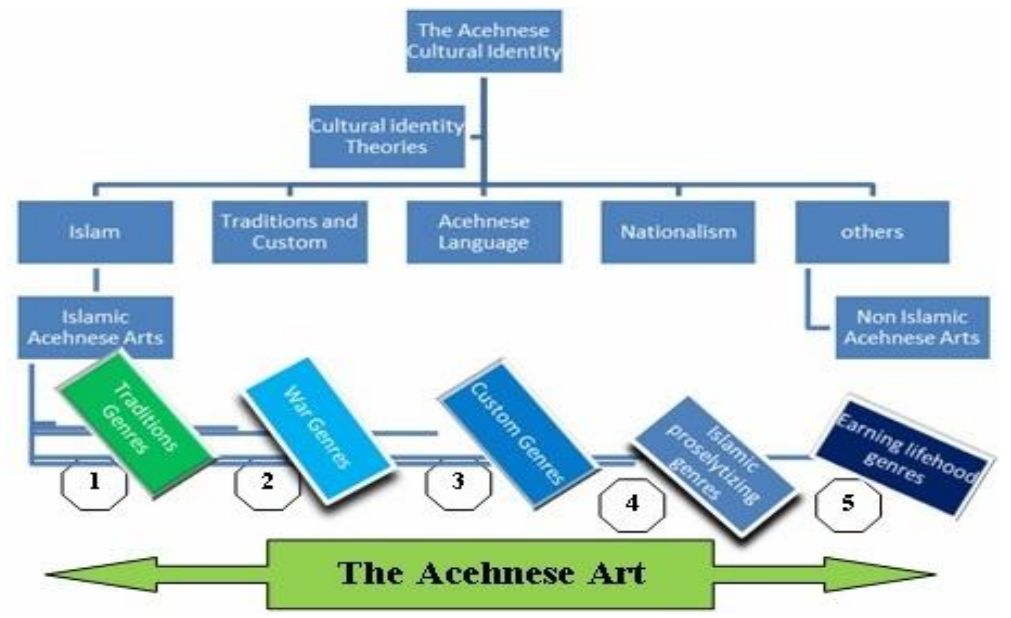

Figure 4: the elements of Acehnese Art and the Acehnese cultural identity

Historically, Acehnese cultural development goes through different phases, when there are, some time, tensions between local values and Islamic values; the traditions and customs, Islamic education and secular one, local patriotism and Indonesian nationalism, as well as external cultures (Dhuhri: 2008a and 2009b; REid: 1979; Siegel: 1969). However, the Acehnese art has always been the anchor for the unity of the Acehnese community. Let's illustrate briefly several examples of the Acehnese arts which explicitly show that the arts can be functioned as the tool to accumulate and raise the Acehnese cultural Identity.

\section{Seudati Dance}

Seudati Dance is a dance that originated from the province of Aceh (Indonesia). Seudati derived from the word Syahadat, which means witness/ testify/ recognition of no god but Allah, and Prophet Muhammad the messenger of the God. This dance also includes categories of Tribal War Dance or War Dance, which evoke the spirit of his verse always Acehnese youth to rise up and fight against colonialism. Therefore, this dance had banned the Dutch colonial era, but now this dance is allowed to return and become the National Arts of Indonesia.

The performance of the Seudati dance can illustrate the points of attaining cultural awareness and collectivity. In the performance of Seudati 
for instance, the audiences along with dancers can benefit the Islamic teaching through the dance's lyric, in the same time; they attain the tradition that represents by the Seudati performance and the social gathering for the dance helps to develop the sense of local collectiveness.

\section{Saman Dance}

Likwise Saman Dance, it is one of the most famous dances which is originated from Acehnese highland; Gayo. Saman lyrics use Arabian language, Aceh and sub-Acehnese language as well. In the past time, Saman dance was usually performed to celebrate important events in tradition and the society in Aceh. Besides, the dance is always performed to celebrate the birth of Muhammad Prophet. In fact, the name of Saman was given from one of famous Islamic Scholar in Aceh, Syech Saman.

This dance which is performed at least by 10 dancers is a very well media to advancement of the Acehnese cultural consciousness. Firstly, the dance was created and developed from the performance of zikri in Sufi ritual by Syeikh Saman. This obviously illustrates the dance is a part of religious activities. Likewise, this dance can be regarded as the tradition for the people gathering, ruminating and mesmerizing their collectiveness. Similarly, the lyric, singing, and the philosophy of the dance teach the audience the importance of collectiveness and unity.

\section{Likok Pulo Dance}

In the same tone, Likok Pulo dance is the Acehnese dance which was composed around 1849, it was created by an Arabian migrated to Aceh for the Islamic proselytizing purpose. The dance depicts the way their barking onto the beach, describing the wind, wave, tree and surroundings. In the later time, the dance has developed to more complex and functioned for the people attaining the Islamic knowledge in its lyric, communal awareness and as the media for political campaign as well.

\section{Hikayat Aceh}

Hikayat is an Acehnese long poem or epic. The name is derived from Arabic language which means "telling story". This art is considered as the greatest and the most amount of the Acehnese arts. The hikayat is 
created based on oral tradition which is initially memorized by the authors and then followed by the audiences.

Acehnese Hikayat contains different aspects of the local life, such as local personal lives, battles, religious event and so forth. Undoubtedly, the Hikayat plays a great role in developing the communal religious beliefs by integrating the locality with the Islamic universal teachings. In addition, Hikayat also integrates the local traditions with external cultures. For this reason, the hikayat was so popular. Similar to the other arts, Hikayat plays a great role to evoke the spirit of ethnicity and communal historical consciousness through heroic battle stories, uphold morality, raising collectiveness from the historical.

Other Acehnese arts are playing the same role, alike Acehnese songs, Acehnese visual arts: painting, calligraphy and handicraft and so forth. Kartomi (2004: 43-44) argues that:

Acehnese ideas of identity are always, of course, in a state of flux as a result of changing social, artistic and cultural experience. Women, men, children, animist mystics, Muslim leaders, former aristocrats, government officials, artists, soldiers and other groups within the community have their own colouring of that sense of identity. However, most seem to agree, for example, that making, playing and listening to musical instruments as well as dancing and other public representational systems serve to articulate the cultural memory and sense of identity; only few-if any-religious leaders subscribe to Wahabi 6 bans on musical instruments and dance.

Even more, the Acehnese art has been a media being used as a uniting factor. In war conditions, Acehnese art had become a great weapon to evoke the spirit to struggle against the Ducth, such as Hikayat Perang Sabii(the epic of the holy war) ${ }^{7}$ (Harun: 1982). In the current time, the Acehnese art have flourished again sparking attentions from Acehnese people from towns and cities. They begin to invite the traditional dancers to dance in most occasions, such as wedding ceremony, the celebration of Prophet Muhammad Birth day and so forth.

${ }^{6}$ It seems that the reason Wahabi does not appreciate the artistic performances due to the belief that practices are forbidden in according to the Islamic teaching.

${ }^{7}$ Hikayat Perang Sabi; the holy war epic is a narrative work explained the virtue of holy war and how the warriors will be awarded for their martyr deeds. 


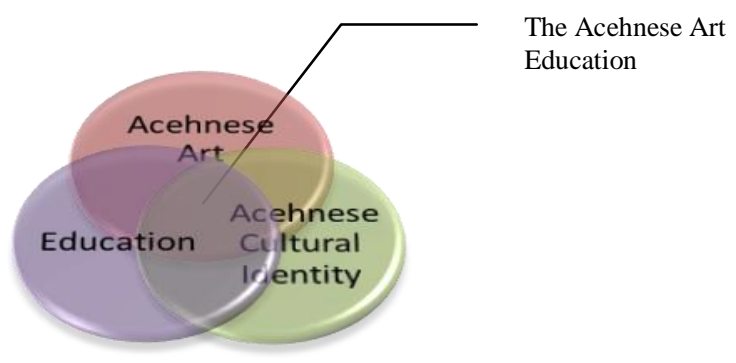

\section{E. Conclusion}

To sum up, this article has shown that Acehnese art great role in creating social cohesion of Acehnese people. This is indicated that Acehnese art has played a great deal in raising the Acehnese collectiveness for the reasons that the arts contain and accommodate all differences among present Acehnese society. In the past, Acehnese people had used the art to maintain the ethnicity and uphold the Islamic teachings, in the present time, art is one of effective media to integrate and advance the Acehnese cultural identity.

\section{Bibliography}

AcehInstitute, F. B. (2008). Problematika Kebudayaan Di Aceh. from Aceh Institute http://.acehinstitute.org/ringkasan_hasil_riset_fdt_budaya_pdf

Andaya, L. Y. (2001). Aceh's Contribution to Standards of Malayness. Archipel, 61, 29-88.

Ar-Raniry, N. (2011). Al-Tibyan fi Ma`rifah Al-Adyan (M. K. Daud, Trans.). Banda Aceh: Pena

Aspinall, E. (2009). Islam and nation : separatist rebellion in Aceh, Indonesia. Stanford, California: Stanford University Press.

Bowen, J. (2007). The New Anthropology of Ethnicity and Identity -and why it Matters for Aceh and Indonesia. Paper presented at the First International Conference of Aceh and Indian Ocean Studies Banda Aceh, Indonesia.

Crickmay, C. (2003). Art and Social Context; Its Background, Inception and Development. Journal of Visual Art Practice, 2, No. 3.

Daudy, A. (1978). Syeikh Nuruddin Ar-Raniry. Darussalam: Bulan bintang.

Dhuhri, S. (2008a). Pendidikan Islam Traditional Aceh: Sejarah Perkembangan Dayah Generasi Baru Peneliti Muslim Indonesia, Mencari Ilmu di Australia, 
Kumpulan Makalah Dosen Penguruan Tinggi Islam Indonesia Peserta Program PERTII 2004-2006. Kingston, Australia: Australia-Indonesia Institute.

Dhuhri, S. (2009b). Peusijuek; Sebuah Tradisi Ritual Sosial Masyarakat Pasee dalam Perspektif Traditionalis dan Reformis (Peusijeuk; a collective ritual of Pasee Community from the Perspective of Traditionalist and Modernist Islam). Paper presented at the International Conference on Aceh and Indian Ocean Studies II Civil Conflict and Its Remedies, Banda Aceh.

Eisner, E. (2007). Art and Knowledge. In J. G. Knowles \& A. L. Cole (Eds.), Handbook of the Arts in Qualitative Research: Perspectives, Methodologies (pp. 3-12). London: SAGE Publications.

El-Ibrahimy, M. N. (1982). Tgk. M. Daud Beureueh; Peranannya dalam Pergolakan di Aceh (Tgk M. Daud Beureueh; his Role in the Conflict in Aceh Jakarta: Gunung Agung.

Government, A. L. (2009). 23 districts or municipals (23 Kabupaten/Kota). from Acehnese Local Government http://www.acehprov.go.id/10;23KabupatenKota

Gramsci, A., Forgacs, D., \& Nowell Smith, G. (1985). Selections from cultural writings. London: Lawrence and Wishart.

Harun, M. Y. (1995). Kerajaan Islam Nusantara abad XVI E XVII. Jakarta: Kurnia Kalam Sejahtera.

Harun, R. (1982). Hikayat Perang Aceh. Jakarta: Departemen Pendidikan dan Kebudayaan, Proyek Penerbitan Buku Sastra Indonesia dan Daerah.

Hatcher, E. P. (1999). Art as Culture: an Introduction to the Anthropology of Art. Westport, Connecticut, London: Bergin \& Garvey.

Hurgronje, C. S. (1985). Aceh di mata kolonialis (Cet. 1. ed.). Jakarta: Yayasan Soko Guru.

Hurgronje, C. S. (1996). Aceh, rakyat dan adat istiadat. Jakarta: INIS.

Ibrahim, M. (1991). Sejarah daerah propinsi Daerah Istimewa Aceh. Jakarta: Proyek Penelitan dan Pencatatan Kebudayaan Daerah, Pusat Penelitian Sejarah dan Budaya, Departemen Pendidikan dan Kebudayaan.

Ismail, M. G. (1993). Pasai dalam perjalanan sejarah : abad ke-13 sampai awal abad ke-16 Jakarta: Proyek Inventarisasi dan Dokumentasi Sejarah 
Nasional, Direktorat Sejarah dan Nilai Tradisional, Direktorat Jenderal Kebudayaan, Departemen Pendidikan dan Kebudayaan.

Joseph, C. (2003). Theorisations of Identity and Difference: Ways of Being Malays, indian and Chinese Schoolgirls in Malaysian Secondary Schools. Doctor of Philosophy, Monash University, Melbourne.

Kartomi, M. (2004). "If a Man Can Kill a Bufallo with One Blow He Can Play a Rapa'i Pasé": How the Frame Drum Expresses Facets of Acehnese Identity. Journal of Chinese Ritual, Theatre and Folkore, No. 144 June 2004.

Khuluq, L. (2002). Strategi Belanda Melumpuhkan Islam. Yogyakarta: Pustaka Pelajar Offset.

Latif, H. A. (1992). Persatuan Ulama Seluruh Aceh (PUSA): its contributions to educational reforms in Aceh. from University Microfilms International (drukker) http://www.acehbooks.org/pdf/ACEH_03332.pdf

Muchsin, M. A. (2015). Art and Entertainment in Islam. Jurnal Ilmiah Peuradeun, 3(1), 133-146.

Mwenesi, L. C. (1998). How is Art and Art Education Relevant for the Construction of a Tanzanian National Cultural Identity within the Context of a Hegemonic Globalism?, University of Alberta, Edmonton, Alberta.

Prang, A. J. (2008). Aceh dari Konflik ke Damai; "Aceh: from conflict to peace". Banda Aceh: Bandar Publishing.

Reid, A. (1979). The Blood of the People; Revolution and the End of Traditional Rule in Northern Sumatra. Oxford, London, Toronto, Kuala Lumpur, Cape Town, Delhi, New York, Melbourne: Oxford University Press.

Reid, A. (2006). Verandah of Violence: The Historical Background of the Aceh Problem. Singapore

Ricci, R. (2011). Islam Translated: Literature, Conversion, and the Arabic Cosmopolis of South and Southeast Asia. London: The University of Chicago Press.

Said, H. M. (1981). Aceh sepanjang abad; Aceh along History. Medan: Waspada.

Siegel, J. T. (1969). The Rope of God. Berkeley and Los Angeles: University of California Press. 
Smith, H. S. (1997). Aceh: art and culture. Kuala Lumpur, Malaysia; New York: Oxford University Press.

Tiro, T. H. d. (1984). The price of freedom: the unfinished diary of Tengku Hasan di Tiro. from National Liberation Front of Acheh Sumatra http://www.acehbooks.org/pdf/ACEH_03654.pdf

Tiro, T. H. M. d. (1979). The drama of Achehnese history : 1873-1978 : a play in VIII acts. from Ministry of Education, State of Acheh, http://www.acehbooks.org/pdf/00371.pdf

Zainuddin, H. M. (1961). Tarich Atjeh dan Nusantara. from Pustaka Iskandar Muda, Medanhttp://www.acehbooks.org/pdf/ACEH_02132.pdf

ZA, T. (2014). Islamic Studies dalam Pendekatan Multidisipliner (Suatu Kajian Gradual Menuju Paradigma Global). Jurnal Ilmiah Peuradeun, 2(2), 211-234. 